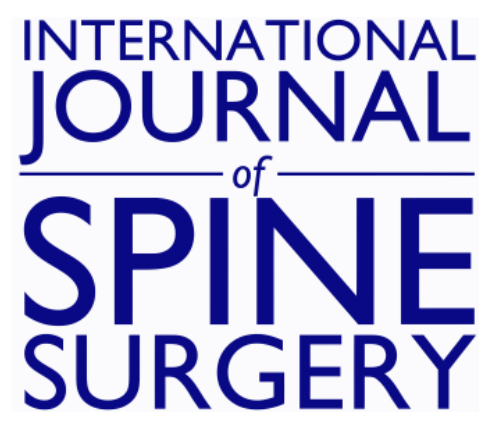

\title{
Polyetheretherketone (PEEK) Rods for Lumbar Fusion: A Systematic Review and Meta-Analysis
}

\author{
ABDULHAFEZ SELIM, SARAH MERCER and FENG TANG
}

Int J Spine Surg 2018, 12 (2) 190-200

doi: https://doi.org/10.14444/5027

http://ijssurgery.com/content/12/2/190

This information is current as of April 26, 2023.

Email Alerts Receive free email-alerts when new articles cite this article. Sign up at:

http://ijssurgery.com/alerts

The International Journal of Spine Surgery

2397 Waterbury Circle, Suite 1,

Aurora, IL 60504, Phone: +1-630-375-1432

(C) 2018 ISASS. All Rights,Refserded 


\title{
Polyetheretherketone (PEEK) Rods for Lumbar Fusion: A Systematic Review and Meta-Analysis
}

\author{
ABDULHAFEZ SELIM, MD, PHD, SARAH MERCER, PHD, FENG TANG, PHD \\ Medtronic Spinal, Memphis, Tennessee
}

\begin{abstract}
Background: The purpose of this systematic review is to evaluate the safety and effectiveness of polyetheretherketone (PEEK) rod systems in patients receiving lumbar interbody fusion treatment. Meta-analyses of relevant clinical data were also conducted when possible.

Methods: Relevant studies were identified by searching the PubMed, EMBASE, and Cochrane Library databases. Clinical studies evaluating the safety and/or effectiveness of the PEEK rod spinal stabilization system in patients receiving lumbar spinal fusion procedure were included. Studies regarding dynamic stabilization and hybrid stabilization (fixed and dynamic; eg, topping-off technique) were not included in this analysis. The analyses included patients who had a lumbar fusion procedure with PEEK rods or titanium rods as a control reference (only for controlled studies). Fusion success, functional and pain improvement, and safety data were evaluated, if reported.

Results: The search yielded 5 studies (1 prospective and 4 retrospectives) that included 177 participants (156 received PEEK rods, and 21 received titanium rods). Meta-analysis of interbody fusion success rate in PEEK rod patients yields the estimate of $95.6 \%$ (confidence interval: $91.6 \%$ to $98.4 \%$ ). Functional outcomes in PEEK rod patients demonstrated clinically significant improvement when comparing postoperative to preoperative scores, with an average improvement of $67.4 \% \pm 8.5 \%$. Similarly, pain improvement was clinically significant with an average visual analog scores-back pain and visual analog scores-leg pain improvement percentages of $68.9 \% \pm 8.6 \%$ and $76.6 \% \pm 1.5 \%$, respectively. Rod fracture was not reported in any of the studies. The rates of screw fracture and loosening were 3/114 $(2.6 \%)$ and $1 / 50(2.0 \%)$, respectively. In the controlled study, no statistically significant difference was reported in the fusion success rate, function improvement, pain improvement, or device-related events between subjects treated with PEEK rods and the subjects treated with titanium rods.
\end{abstract}

Conclusions: Experience with PEEK rod systems has shown satisfactory clinical outcomes. Therefore, these results support the use of PEEK rod systems as supplemental fixation during lumbar fusion procedures.

Lumbar Spine

Keywords: PEEK rod, lumbar fusion, DDD, fusion success, titanium rod, ODI, VAS

\section{INTRODUCTION}

Instrumented spinal arthrodesis using rigid rods is currently the most widely used treatment for degenerative diseases of the lumbar spine, particularly if unresponsive to conservative care. However, the elastic modulus of titanium, the main metallic material used in lumbar fusion procedures, is much greater than that of bone, which may significantly change the physiological distribution of the load at the instrumented vertebral segments. ${ }^{1-3}$

Semirigid systems have been proposed to avoid rigid fixation to prevent adjacent segment degeneration. Polyetheretherketone (PEEK) rods have become available as an alternative to metal rods for use with pedicle screws to perform posterior lumbar fusion. PEEK has a modulus of elasticity between that of cortical and cancellous bones, thus mimicking the features of the physiological environment. ${ }^{3-5}$ Additionally, PEEK rods are associated with a substantial reduction in stress-shielding characteristics, which reduces the stress on the pedicle screws and may decrease the risk of failure, especially in osteoporotic bone. ${ }^{3,5}$ Furthermore, PEEK is translucent to $\mathrm{X}$-rays, so these rods cause fewer artifacts on computed tomography scans making radiologic follow-up easier. ${ }^{6}$

Two reviews were previously published on the use of PEEK rod systems for spine disorders. ${ }^{7,8}$ However, the authors of both studies did not analyze the fusion and dynamic stabilization data separately. Since the differences in patient population, indications, and biomechanics in these 2 groups (fusion patients versus dynamic stabilization 


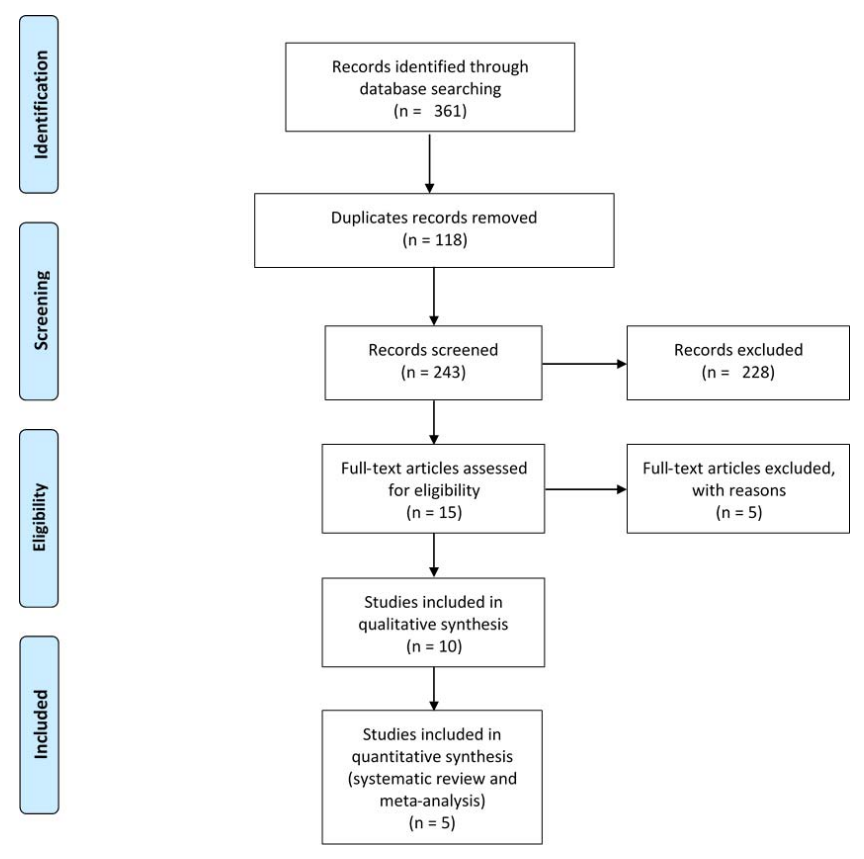

Figure 1. The flow diagram of study selection.

patients) may impact the quality and/or the value/ usability of the data, this project was conducted to evaluate the clinical data in lumbar fusion patients only (ie, no dynamic stabilization data were included in our analyses). In this study, we analyzed fusion success rates, pain/function improvement data, and device-related data in patients who received PEEK rods for interbody fusion (IBF). Subgroup analyses included fusion rates per number of treated levels, and per graft type. These analyses were used to appraise the risk-benefit profile of PEEK rods in lumbar IBF indication.

\section{METHODS}

\section{Search Strategy and Study Selection}

A literature search of the PubMed, EMBASE, and Cochrane Library databases was conducted independently by 2 authors (A.S. and S.M.) to identify relevant studies (controlled or not controlled) evaluating the use of PEEK rod spinal stabilization systems in lumbar spine fusion patients. The literature search was completed on July 20, 2017. The search was not restricted by language or date of publication. The following keywords or phrases in various combinations were utilized: PEEK rod or polyetheretherketone rod or semirigid rod or semi-rigid rod or semi rigid rod or $\mathrm{CD}$ Horizon. After reviewing the titles and abstracts, 2 authors (A.S. and S.M.) identified potentially

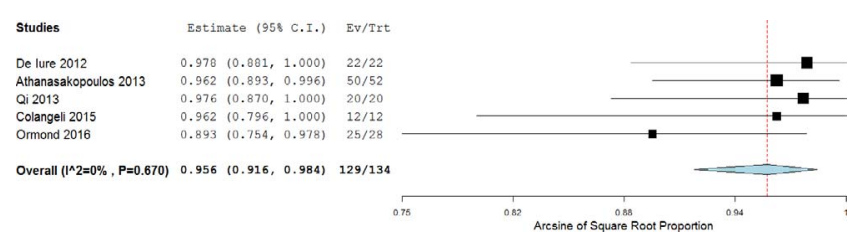

Figure 2. Forest plot with point estimate (95\% confidence interval $[\mathrm{Cl}])$ of the fusion success rates established based on binary random effects model in patients treated with interbody fusion along with polyetheretherketone (PEEK) rod systems. The posterolateral fusion cases (8) in De lure et al. ${ }^{16}$ were not included in this meta-analysis.

eligible studies, and full texts of identified articles were examined for eligibility. Exclusion criteria were as follows: dynamic stabilization, topping off/ topping down, biomechanical, cadaver, in vitro, or animal studies. Any disagreement was resolved through consensus (Figure 1).

\section{Data Extraction and Presentation}

Data extraction was independently conducted by 2 assessors (A.S. and F.T.). Any disagreements were resolved through consensus. The following data were extracted: author; year; study type; publication type; mono- or multi-centric study type; surgery dates; number of patients; preoperative pathology/ diagnosis; rates of fusion success, rod fracture, screw fracture, and screw loosening; functional outcomes (Japanese Orthopedic Association [JOA] or Oswestry Disability Index [ODI] scores); visual analog score (VAS); surgical procedure; bone graft used; cage used; and follow-up period. Fusion success rates, VAS, functional improvement, rod fracture, screw fracture, and screw loosening data were extracted according to the methods in Table 1.

\section{Statistical Analysis}

Meta-analysis is the statistical procedure for combining data from multiple studies when the result from a single study is not very reliable or not very convincing. OpenMeta Analyst software ${ }^{9}$ was employed as a tool for conducting the meta-analysis of the fusion success rates in the noncontrolled studies (Figure 2). Because of the importance of confounding variables such as graft type, and the number of treated levels, subgroup analyses were conducted by including these variables as explanatory variables.

Descriptive statistics were used for assessment of the device-related events as well as ODI, JOA, and VAS data. 
Table 1. Data extraction and presentation methods.

\begin{tabular}{|c|c|c|c|}
\hline Item & $\begin{array}{c}\text { Data Presentation Formats in the } \\
\text { Articles }\end{array}$ & $\begin{array}{c}\text { Data Presentation Formats in This } \\
\text { Study }\end{array}$ & Notes \\
\hline Fusion success rate & $\begin{array}{l}\text { Numerator/denominator format (ie, } \\
\text { fusion success/total) } \\
\text { Fusion success rates } \\
\text { Pseudoarthrosis (nonunion) rates }\end{array}$ & $\begin{array}{l}\text { Data were presented in numerator/ } \\
\text { denominator format (ie, fusion } \\
\text { success/total). }\end{array}$ & $\begin{array}{l}\text { Fusion success data at the latest } \\
\text { endpoint were used for further } \\
\text { analysis. }\end{array}$ \\
\hline $\begin{array}{l}\text { Functional outcomes } \\
\text { (ODI or JOA) }\end{array}$ & $\begin{array}{l}\text { Scores at preoperative and at various } \\
\text { postoperative time points } \\
\text { Percentage of improvement at } \\
\text { various postoperative time points }\end{array}$ & $\begin{array}{l}\text { Scores were used to calculate the } \\
\text { improvement percentage at the } \\
\text { latest time point: (difference } \\
\text { between preop score and latest } \\
\text { post-op score)/preop score } \times 100 \text {. }\end{array}$ & $\begin{array}{l}\text { In one occasion, data were } \\
\text { deduced from the representative } \\
\text { graphs and this was indicated at } \\
\text { the related table(s). }\end{array}$ \\
\hline VAS & $\begin{array}{l}\text { Scores at preoperative and at various } \\
\text { postoperative time points } \\
\text { Percentage of improvement at } \\
\text { various postoperative time points }\end{array}$ & $\begin{array}{l}\text { Scores were used to calculate the } \\
\text { improvement percent at the latest } \\
\text { time point: (difference between } \\
\text { preop score and latest postop } \\
\text { score)/preop score } \times 100 \text {. }\end{array}$ & $\begin{array}{l}\text { In some occasions, improvement } \\
\text { rates were deduced from their } \\
\text { representative graphs and this } \\
\text { was indicated at the related } \\
\text { table(s). }\end{array}$ \\
\hline $\begin{array}{l}\text { Device-related events } \\
\text { (rod fracture, screw } \\
\text { fracture, and screw } \\
\text { loosening) }\end{array}$ & $\begin{array}{l}\text { Specific adverse events (if any) } \\
\text { No instrumentation failure } \\
\text { No device-related events }\end{array}$ & $\begin{array}{l}\text { In case of reported events, the } \\
\text { numerator/denominator format } \\
\text { was used }\end{array}$ & \\
\hline
\end{tabular}

Abbreviations: ODI, Oswestry Disability Index score; JOA, Japanese Orthopedic Association score; VAS, visual analog score.

\section{RESULTS}

\section{Characteristics of the Analyzed Articles}

As shown in Figure 1, potentially eligible studies were identified by electronic search. After excluding duplicates, 243 records were selected. 228 studies were excluded because they did not meet the inclusion criteria based on their titles and abstracts. It is important to mention that the dynamic stabilization studies ${ }^{10-12}$ or the hybrid stabilization studies $^{13,14}$ were not included. After reviewing the full text, 5 studies were finally included for the quantitative analysis.

The analyses included 1 prospective and 4 retrospectives studies. One study included a titanium rod control group. The follow-up period varied from 12 months up to 36 months, with an average follow-up time of $24.1 \pm 11.3$ months. All studies reported patient-related outcomes with evidence levels of III and IV according to the North American Spine Society classification system. ${ }^{15}$ For additional details, please see Tables 2 to 4 .

\section{Study Patients}

The studies included 156 PEEK rod patients with an average age of $52.8 \pm 6.5$ years. The average percentage of females was $44.5 \% \pm 5.8 \%$. Average follow-up period was $24.1 \pm 11.3$ months. The preoperative diagnoses/pathologies included stenosis, segmental instability, recurrent disc herniation, spondylolisthesis, axial back pain with lower extremity weakness, vertebral fracture, and tumor (Table 5).

\section{Surgical Techniques and Procedures}

Lumbar IBF was used in most of the studies (Table 6). The open surgical technique was used in all studies. The studies included the use of various graft types and the treatment of single as well as multiple levels. The following bone grafts were used: autograft alone and autograft mixed with demineralized bone matrix (DBM). Fusion success rate analyses were conducted for IBF only. For additional details, see Tables 6 and 7 .

Table 2. List of the analyzed studies.

\begin{tabular}{|c|c|c|c|c|c|c|}
\hline Author & Year & Cohort & $\begin{array}{l}\text { PEEK Rod } \\
\text { Patients }\end{array}$ & $\begin{array}{c}\text { Control Patients } \\
\text { (Using Titanium Rods) }\end{array}$ & Total & $\begin{array}{l}\text { Extracted } \\
\text { Outcomes }^{\mathrm{a}}\end{array}$ \\
\hline De Iure et al. ${ }^{16}$ & 2012 & Retrospective & 30 & NA & 30 & $\mathrm{~S}, \mathrm{~F}$ \\
\hline Athanasakopoulos et al. ${ }^{17}$ & 2013 & Retrospective & 52 & NA & 52 & $\mathrm{~S}, \mathrm{~F}, \mathrm{~V}, \mathrm{FI}$ \\
\hline Qi et al. ${ }^{18}$ & 2013 & Prospective & 20 & 21 (titanium) & 41 & $\mathrm{~S}, \mathrm{~F}, \mathrm{~V}, \mathrm{FI}$ \\
\hline Colangeli et al. ${ }^{19}$ & 2015 & Retrospective & 12 & $\mathrm{NA}^{\mathrm{a}}$ & 12 & $\mathrm{~S}, \mathrm{~F}, \mathrm{~V}, \mathrm{FI}$ \\
\hline Ormond et al. ${ }^{20}$ & 2016 & Retrospective & 42 & NA & 42 & $\mathrm{~S}, \mathrm{~F}$ \\
\hline Summary & & 1 prospective, 4 retrospective & 156 & 21 & 177 & \\
\hline
\end{tabular}

Abbreviations: PEEK, polyetheretherketone; S, safety data; V, visual analog score data; F, fusion data; FI, functional improvement data (Oswestry Disability Index or Japanese Orthopedic Association scores).

${ }^{\mathrm{a}} 12$ patients who used Nflex rods were not included in any analysis because they are not comparable to PEEK or titanium rods. 
Table 3. Literature appraisal.

\begin{tabular}{|c|c|c|c|c|}
\hline Author & Year & $\begin{array}{c}\text { Device- } \\
\text { Related } \\
\text { Data }\end{array}$ & $\begin{array}{c}\text { Patient- } \\
\text { Related } \\
\text { Data }\end{array}$ & $\begin{array}{c}\text { Evidence } \\
\text { Level }^{15}\end{array}$ \\
\hline De Iure et al. ${ }^{16}$ & 2012 & + & + & IV \\
\hline Athanasakopoulos et al. ${ }^{17}$ & 2013 & + & + & IV \\
\hline Qi et al. ${ }^{18}$ & 2013 & + & + & III \\
\hline Colangeli et al. ${ }^{19}$ & 2015 & + & + & III \\
\hline Ormond et al. ${ }^{20}$ & 2016 & + & + & IV \\
\hline
\end{tabular}

\section{Safety Results}

Device-related events (rod fracture and screw loosening/fracture) were extracted and analyzed for PEEK rod-treated subjects. Rod fracture was not reported in any of the studies. The rates of screw fracture and loosening were $3 / 114(2.6 \%)$ and $1 / 50$ $(2.0 \%)$, respectively. The rates of screw fracture ranged from $0.0 \%$ to $3.8 \%$ and the rates of screw loosening ranged from $0.0 \%$ to $3.3 \%$ (Table 8 ). Data from the controlled studies demonstrated no statistically significant difference in the rates of device-related events in the PEEK treatment group as compared to that in the titanium control group (Table 9).

\section{Effectiveness Results}

\section{Fusion Success Rate}

Fusion success rates were reported for 142 PEEK rod patients in 5 studies. Most of these patients received $\operatorname{IBF}(134 / 142 ; 94.4 \%)$. The remaining patients $(8 / 142 ; 5.6 \%)$ received posterolateral fusion (PLF). In this review, fusion success rate analyses were conducted for IBF only.

The meta-analysis estimate for fusion success rate in patients having IBF is $95.6 \%$ (confidence interval: $91.6 \%$ to $98.4 \%$ ) (Table 6; Figure 2). It is important to mention that the lowest fusion success rate was reported in Ormond et al. $(89.3 \%){ }^{20}$ However, this particular study had a high percentage of smokers $(42.8 \%)$, and we observed that 2 out of the 3 nonfusion cases were smokers, ${ }^{20}$ which

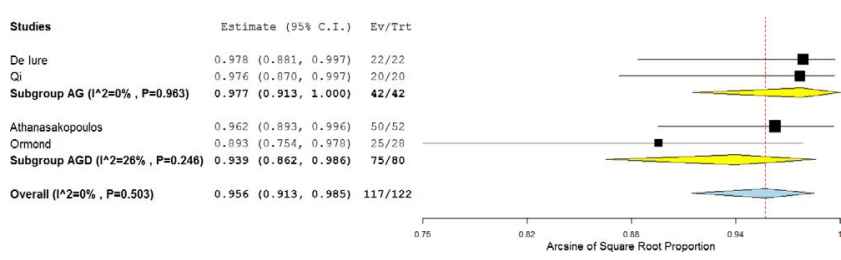

Figure 3. Forest plot with point estimate (95\% confidence interval $[\mathrm{Cl}])$ of the fusion success rates established based on binary random effects model in patients treated with interbody fusion along with polyetheretherketone (PEEK) rod systems per graft type. Abbreviations: AG, autograft only; AGD, autograft + demineralized bone matrix.
Table 4. High-level summary of the analyzed studies.

\begin{tabular}{lcc}
\hline Item & Summary & Notes \\
\hline Total no. of studies & 5 & \\
Total no. of PEEK rod patients & 156 & $\begin{array}{c}\text { Total no. including } \\
\text { control patients }\end{array}$ \\
& & $\begin{array}{l}\text { is } 177 \\
\text { Monocentric studies }\end{array}$ \\
Prospective studies & $5 / 5$ & \\
Retrospective studies & $1 / 5$ & \\
Studies with titanium control group & $4 / 5$ & \\
\end{tabular}

Abbreviation: PEEK, polyetheretherketone.

could be the reason for a relative lower fusion success rate than the other studies.

Because of the importance of confounding variables such as graft type and the number of treated levels, we further conducted subgroup analyses for these 2 variables. Slightly higher fusion success rate was observed in studies having IBF with autograft only compared to autograft and DBM $(97.7 \%$ versus $93.9 \%$, respectively) (Figure 3 ). Regarding the number of treated levels, since no patient-level fusion data were available, a conservative approach was used by classifying the studies into 2 subgroups: studies that included only singlelevel-treated patients (SL) versus studies that included single as well as multiple-level-treated patients (ML). Similar fusion success rates were observed in SL and ML studies; point estimates of $93.8 \%$ and $95.6 \%$, respectively (Figure 4).

\section{Fusion Data in the Controlled Studies}

Qi et al. ${ }^{18}$ reported $100 \%$ fusion rates in both treatment groups. Meta-analysis assessment was not feasible because of lack of enough study number. For additional information, please see Table 10.

\section{Functional Improvement Outcomes in PEEK Rod Patients}

Functional improvement data were reported in 3 out of the 5 studies (Table 11). Functional

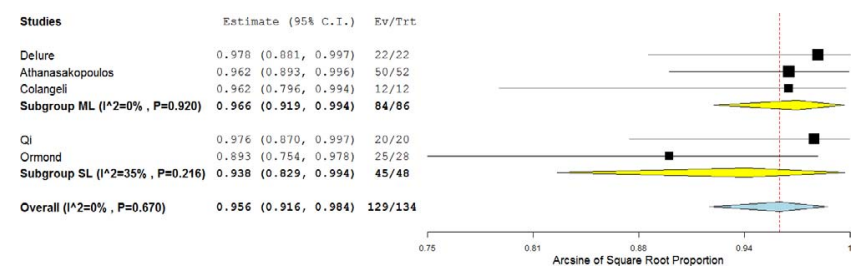

Figure 4. Forest plot with point estimate (95\% confidence interval [CI]) of the fusion success rates established based on binary random effects model in patients treated with interbody fusion along with polyetheretherketone (PEEK) rod systems per the number of treated levels. Abbreviations: SL, the study included only single-level-treated patients; ML, the study included single as well as multiple-level-treated patients. 
PEEK Rods for Lumbar Fusion: A Systematic Review and Meta-Analysis

Table 5. Baseline data of the PEEK rod-treated patients.

\begin{tabular}{|c|c|c|c|c|c|}
\hline Author & Year & $\begin{array}{l}\text { Patient Population (Diagnoses/Preoperative } \\
\text { Pathology) }\end{array}$ & $\begin{array}{l}\text { Age Mean } \\
(y)\end{array}$ & $\begin{array}{c}\text { Female } \\
(\mathrm{m} / \mathrm{n}, \%)\end{array}$ & $\begin{array}{l}\text { Follow-Up } \\
\text { Period Mean } \\
\quad(\text { mo })\end{array}$ \\
\hline De Iure et al. ${ }^{16}$ & 2012 & $\begin{array}{l}\text { Multilevel spinal stenosis with claudication, } \\
\text { segmental spinal stenosis, symptomatic } \\
\text { low-grade spondylolisthesis, painful DDD, } \\
\text { and recurrent disc herniation }\end{array}$ & 61 & $17 / 30,56.7$ & 12 \\
\hline Athanasakopoulos et al. ${ }^{17}$ & 2013 & $\begin{array}{l}\text { DDD (25), lateral recess stenosis (10), } \\
\text { combined lateral recess stenosis and } \\
\text { degenerative spondylolisthesis (4), } \\
\text { degenerative spondylolisthesis (6), lumbar } \\
\text { spine vertebral fracture (6), and an L5 } \\
\text { giant cell tumor (1) }\end{array}$ & 55.4 & $29 / 52,55.8$ & 36 \\
\hline Qi et al. ${ }^{18}$ & 2013 & $\begin{array}{l}\text { Lumbar disc herniation with segmental } \\
\text { instability, lumbar spondylotic stenosis } \\
\text { with segmental instability, or low-grade } \\
\text { degenerative lumbar spondylolisthesis. }\end{array}$ & $\begin{array}{l}50.4 \text { for PEEK, } 48.9 \\
\text { for control }\end{array}$ & $\begin{array}{l}9 / 20,45.0 \% \text { for } \\
\text { PEEK, and } 10 / 21, \\
47.6 \% \text { for control }\end{array}$ & 12 \\
\hline Colangeli et al. ${ }^{19}$ & 2015 & $\begin{array}{l}\text { All patients presented lumbar DDD with } \\
\text { spondylolisthesis, disc herniation, or } \\
\text { stenosis. }\end{array}$ & 43.3 & $3 / 12,25.0$ & 29.1 \\
\hline Ormond et al. ${ }^{20}$ & 2016 & $\begin{array}{l}\text { Axial back pain with or without } \\
\text { radiculopathy and lower extremity } \\
\text { weakness }\end{array}$ & 53.7 & $17 / 42,40.5$ & 31.4 \\
\hline Summary & & & $52.8 \pm 6.5^{\mathrm{a}}$ & $44.6 \% \pm 13.0^{\mathrm{a}}$ & $24.1 \pm 11.3$ \\
\hline
\end{tabular}

Abbreviations: PEEK, polyetheretherketone; DDD, degenerative disc disease.

${ }^{a}$ Based on the PEEK subjects, not including the control subjects.

improvement data were presented as scores (preand postoperative scores at various time points) or as percentage of improvement of ODI (2 studies) or JOA (1 study) scores. To have comparable data, we calculated the percentage of improvements as the difference between pre- and postoperative scores/ (preoperative score $\times 100$ ). In these 3 studies, PEEK rod patients (84) had clinically significant improvement when comparing postoperative to preoperative scores, with an average improvement of $67.4 \% \pm 8.5 \%$ (Table 11 ). Meta-analysis was not feasible due to the lack of essential numerical data (SD or SE).

\section{Functional Improvement in the Controlled Studies} Qi et al. ${ }^{18}$ reported that clinically meaningful improvement was observed in both groups when comparing the preoperative to the postoperative data (Table 12). Additionally, the authors reported that there was no statistically significant difference between the treatment groups (Table 12). Metaanalysis was not feasible due to the lack of sufficient number of studies.

\section{Pain Improvement Outcomes in PEEK Rod Patients}

Pain improvement data of PEEK rod patients were reported in 3 out of 5 studies (Table 13). Pain improvement data were presented as scores (preand postoperative scores at various timepoints) or as percentage of improvement. To have comparable data, we calculated the percentages of improvement as the difference between pre- and postoperative scores/(pre-operative score $\times 100)$. In all studies, PEEK patients had clinically meaningful improvement when comparing postoperative to preoperative data (Table 13). Two ${ }^{17,18}$ out of those 3 studies reported detailed pain data: visual analog scoresback pain (VAS-BP) and visual analog scores-leg pain (VAS-LP) data. Average VAS-BP and VAS-LP improvement percentages of $68.9 \% \pm 8.6 \%$ and $76.6 \% \pm 1.5 \%$, respectively, were observed (Table 13). In the third study, ${ }^{19}$ overall pain improvement of $57.9 \%$ was reported. Meta-analysis was not feasible due to the lack of sufficient number of studies.

\section{Pain Improvement in the Controlled Studies}

Qi et al. ${ }^{18}$ reported VAS-BP and VAS-LP scores separately. VAS-LP scores improved significantly at 3 months, 6 months, and 1 year postoperatively compared with the preoperative scores $(P<.001)$ in both groups. No significant differences were seen between the treatment groups at the same time points $(P>.05)$ (Table 14).

\section{Other Findings}

Disc Height (DH). Qi et al. ${ }^{18}$ examined DH preoperatively and postoperatively. DH increased significantly at 1 week and 1 year postoperatively 
Table 6. Overall summary of the fusion data in PEEK rod-treated patients.

\begin{tabular}{|c|c|c|c|c|c|c|c|}
\hline Author & Year & $\begin{array}{l}\text { PEEK Rod } \\
\text { Patients (n) }\end{array}$ & Raw Data & $\begin{array}{l}\text { No. of Successful } \\
\text { Fusions/Total } \\
\text { No. (\%) }\end{array}$ & $\begin{array}{l}\text { Graft } \\
\text { Type }\end{array}$ & $\begin{array}{c}\text { Fusion } \\
\text { Procedure }\end{array}$ & $\begin{array}{l}\text { No. of } \\
\text { Treated } \\
\text { Levels }\end{array}$ \\
\hline De Iure et al. ${ }^{16}$ & 2012 & 30 & $\begin{array}{l}\text { In the group of } 22 \\
\text { patients in whom } \\
\text { anterior interbody } \\
\text { cages were implanted, } \\
\text { a clear fusion was } \\
\text { visible in } 18 \text { patients } \\
\text { at } 6 \text { months and in } \\
\text { all the patients at } 12 \\
\text { months. } \\
\text { In the } 8 \text { patients who } \\
\text { received } \\
\text { posterolateral } \\
\text { autogenous grafting } \\
\text { only, } 4 \text { patients were } \\
\text { fused at } 6 \text { months } \\
\text { and } 7 \text { patients at } 1 \\
\text { year. }\end{array}$ & $\begin{array}{l}\text { IBF: } 22 / 22 \\
\quad(100.0 \%) \\
\text { PLF: } 7 / 8 \\
(87.5 \%)\end{array}$ & $\mathrm{AG}$ & $\begin{array}{l}\text { IBF (22); PLF } \\
\quad(8)\end{array}$ & $\begin{array}{l}2.9 \text { (average), } \\
\text { range: } 2-5\end{array}$ \\
\hline $\begin{array}{l}\text { Athanasakopoulos } \\
\text { et al. }{ }^{17}\end{array}$ & 2013 & 52 & $\begin{array}{l}\text { Imaging evidence of } \\
\text { new bone formation } \\
\text { was observed in } 50 \\
(96 \%) \text { patients by } 1- \\
\text { year follow-up; } 2 \\
\text { patients developed no } \\
\text { imaging signs of } \\
\text { union during follow- } \\
\text { up. }\end{array}$ & $50 / 52(96.2 \%)$ & $\mathrm{AG}+\mathrm{DBM}$ & IBF & $\begin{array}{l}1(10), 2 \text { (29), } 3 \\
\quad(13)\end{array}$ \\
\hline Qi et al. ${ }^{18}$ & 2013 & 20 & $\begin{array}{l}\text { The overall fusion rate } \\
\text { was } 100.0 \% \text { at the } \\
\text { 1-year follow-up for } \\
\text { both groups. }\end{array}$ & $20 / 20(100.0 \%)$ & $\mathrm{AG}$ & IBF & $1(20)$ \\
\hline Colangeli et al. ${ }^{19}$ & 2015 & 12 & $\begin{array}{l}\text { All the patients } \\
\text { presented bony } \\
\text { fusion at 6-month } \\
\text { follow-up. }\end{array}$ & $12 / 12(100.0 \%)$ & NR & IBF & $1(9), 2(3)$ \\
\hline Ormond et al. ${ }^{20}$ & 2016 & 42 & $\begin{array}{l}\text { Fusion data were } \\
\text { available for } 28 \\
\text { patients only, } 25 \text { of } \\
\text { whom demonstrated } \\
\text { fusion }(89.3 \%) \text {. All } \\
\text { patients } \\
\text { radiographically } \\
\text { fused were confirmed } \\
\text { by CT scan. }\end{array}$ & $25 / 28(89.3 \%)$ & $\mathrm{AG}+\mathrm{DBM}$ & IBF & $1(42)$ \\
\hline Summary & & 156 & & $\begin{array}{l}\text { Fusion data are } \\
\text { available for } \\
142 \text { patients: } \\
\text { IBF rate based } \\
\text { on pooled } \\
\text { data: } 96.3 \% \\
\text { (129/134) } \\
\text { PLF rate: } 87.5 \% \\
\text { (7/8) }\end{array}$ & $\begin{array}{l}\text { NS: } 7.7 \%(12 / \\
\text { 156), AG: } \\
32.1 \%(50 / \\
156), \\
\text { AG + DBM: } \\
60.3 \%(94 / \\
156)\end{array}$ & $\begin{array}{l}\text { IBF: } 94.9 \% \\
\quad(148 / 156) \\
\text { PLF: } 5.1 \% \\
(8 / 156)\end{array}$ & \\
\hline
\end{tabular}

Abbreviations: PEEK, polyetheretherketone; IBF, interbody fusion; PLF, posterolateral fusion; AG, autograft; DBM, demineralized bone matrix; NS, not specified; CT, computed tomography; NR, not reported.

compared with the preoperative data $(P<.01)$ in both groups (PEEK and titanium). Patients in the PEEK group showed no significant differences in disc space height at 1 week and 1 year postoperatively as compared with patients in the titanium group $(P>.05)$. Moreover, the increase rate of disc space height at 1 week postoperatively (defined as [1-week postoperative $\mathrm{DH}$ - preoperative $\mathrm{DH}]$ /pre- operative $\mathrm{DH} \times 100 \%$ ) and the loss rate of $\mathrm{DH}$ at 1 year postoperatively (defined as [1-week postoperative $\mathrm{DH}-1$-year postoperative $\mathrm{DH}] / 1$-week postoperative $\mathrm{DH} \times 100 \%$ ) were calculated. The postoperative increase of $\mathrm{DH}$ and loss of $\mathrm{DH}$ during the follow-up showed a similar extent of change between both groups $(P>.05)$. Authors concluded that the loss of $\mathrm{DH}$ could be found 
PEEK Rods for Lumbar Fusion: A Systematic Review and Meta-Analysis

Table 7. Details on the number of treated levels and graft types in patients received interbody fusion using PEEK rods.

\begin{tabular}{|c|c|c|c|c|c|c|c|}
\hline Author & Year & $\begin{array}{l}\text { PEEK Rod } \\
\text { Patients (n) }\end{array}$ & 1 Level (n) & 2 Levels (n) & 3 Levels (n) & $\begin{array}{c}\text { Not Specified } \\
\text { Multiple Levels (n) }\end{array}$ & Graft Type \\
\hline DeIure et al. ${ }^{16}$ & 2012 & 22 & 0 & 0 & 0 & 22 & $\mathrm{AG}$ \\
\hline Athanasakopoulos et al. ${ }^{17}$ & 2013 & 52 & 10 & 29 & 13 & 0 & $\mathrm{AG}+\mathrm{DBM}$ \\
\hline Qi et al. ${ }^{18}$ & 2013 & 20 & 20 & 0 & 0 & 0 & $\mathrm{AG}$ \\
\hline Colangeli et al. ${ }^{19}$ & 2015 & 12 & 9 & 3 & 0 & 0 & NR \\
\hline Ormond et al. ${ }^{20}$ & 2016 & 28 & 28 & 0 & 0 & 0 & $\mathrm{AG}+\mathrm{DBM}$ \\
\hline Total & & 134 & 67 & 32 & 13 & 22 & \\
\hline
\end{tabular}

Abbreviations: PEEK, polyetheretherketone; AG, autograft; DBM, demineralized bone matrix; NR, not reported.

Table 8. Summary of device-related events in PEEK rod patients.

\begin{tabular}{|c|c|c|c|c|c|c|}
\hline \multirow[b]{2}{*}{ Author } & \multirow[b]{2}{*}{ Year } & \multirow[b]{2}{*}{$\begin{array}{l}\text { Total No. } \\
\text { of PEEK } \\
\text { Patients }\end{array}$} & \multirow[b]{2}{*}{ Raw Data } & \multicolumn{3}{|c|}{ Extracted Data } \\
\hline & & & & $\begin{array}{l}\text { Patients With } \\
\quad \text { Rod } \\
\text { Fractures (n) }\end{array}$ & $\begin{array}{l}\text { Patients With } \\
\text { Screw } \\
\text { Fracture (n) }\end{array}$ & $\begin{array}{l}\text { Patients With } \\
\text { Screw } \\
\text { Loosening (n) }\end{array}$ \\
\hline De Iure et al. ${ }^{16}$ & 2012 & 30 & $\begin{array}{l}\text { Only one case required surgical revision } \\
\text { for a mechanical complication; one } \\
\text { patient exhibited screw mobilization at } \\
\text { 8-month follow-up. }\end{array}$ & NS & NS & $1 / 30(3.3 \%)$ \\
\hline Athanasakopoulos et al. ${ }^{17}$ & 2013 & 52 & Two patients sustained screw breakage. & NS & $2 / 52(3.8 \%)$ & NS \\
\hline Qi et al. ${ }^{18}$ & 2013 & 20 & $\begin{array}{l}\text { No complications from instrumentation } \\
\text { were noted. Neither screw } \\
\text { displacement nor screw failure was } \\
\text { detected in any of the patients at the } \\
\text { follow up. }\end{array}$ & NS & $0 / 20(0.0 \%)$ & $0 / 20(0.0 \%)$ \\
\hline Colangeli et al. ${ }^{19}$ & 2015 & 12 & No patient had any complications. & NS & NS & NS \\
\hline Ormond et al. ${ }^{20}$ & 2016 & 42 & $\begin{array}{l}\text { Reasons for reoperation included } \\
\text { instrumentation failure from a } \\
\text { fractured screw (1). }\end{array}$ & NS & $1 / 42(2.4 \%)$ & NS \\
\hline Total & & 156 & & & $3 / 114(2.6 \%)^{\mathrm{a}}$ & $1 / 50(2.0 \%)^{\mathrm{a}}$ \\
\hline
\end{tabular}

Abbreviations: PEEK, polyetheretherketone; NS: not specified. NS implies that results did not indicate the occurrence of this event. However, authors did not give enough specific details sufficient to extract numerical data.

${ }^{a}$ Denominators vary according to the data availability for each category.

Table 9. Summary of device-related events in the controlled studies (PEEK versus titanium rods).

\begin{tabular}{|c|c|c|c|c|c|c|c|c|c|c|c|}
\hline \multirow[b]{3}{*}{ Study } & \multirow[b]{3}{*}{ Year } & \multirow[b]{3}{*}{ Raw Data } & \multicolumn{9}{|c|}{ Extracted Data } \\
\hline & & & \multicolumn{3}{|c|}{ Titanium } & \multicolumn{3}{|c|}{ PEEK } & \multicolumn{3}{|c|}{$\begin{array}{c}\text { Titanium-PEEK Rate } \\
\text { of Difference }\end{array}$} \\
\hline & & & SL & SF & $\mathbf{R F}$ & SL & SF & RF & SL & SF & RF \\
\hline Qi et al. ${ }^{18}$ & 2013 & $\begin{array}{l}\text { Neither screw displacement } \\
\text { nor screw failure was } \\
\text { detected for any of the } \\
\text { patients at the follow-up. } \\
\text { No titanium alloy rod } \\
\text { failure was found in the } \\
\text { titanium group. }\end{array}$ & $\begin{array}{c}0 / 21 \\
(0.0 \%)\end{array}$ & $\begin{array}{c}0 / 21 \\
(0.0 \%)\end{array}$ & $\begin{array}{c}0 / 21 \\
(0.0 \%)\end{array}$ & $\begin{array}{c}0 / 20 \\
(0.0 \%)\end{array}$ & $\begin{array}{c}0 / 20 \\
(0.0 \%)\end{array}$ & NS & $0.0 \%$ & $0.0 \%$ & NA \\
\hline
\end{tabular}

Abbreviations: PEEK, polyetheretherketone; SL, screw loosening; SF, screw fracture; RF, rod fracture; NS, not specified; NA, not applicable.

Table 10. Fusion data in the controlled studies (PEEK versus titanium rods).

\begin{tabular}{llcl}
\hline Study & $\begin{array}{c}\text { Control (n), } \\
\text { Fusion Rate }(\%)\end{array}$ & $\begin{array}{c}\text { PEEK (n), } \\
\text { Fusion Rate }(\%)\end{array}$ & Notes \\
\hline Qi et al. ${ }^{18}$ & $21 / 21(100.0 \%)$ & $20 / 20(100.0 \%)$ & The overall fusion success rate was $100.0 \%$ at the $1-y e a r$ follow-up for both groups. \\
\hline
\end{tabular}

Abbreviation: PEEK, polyetheretherketone. 
Table 11. Overall summary of the functional improvement data in PEEK rod patients.

\begin{tabular}{|c|c|c|c|c|c|}
\hline Author & Year & $\begin{array}{c}\text { Functional } \\
\text { Test }\end{array}$ & $\begin{array}{c}\text { PEEK } \\
\text { Rod } \\
\text { Patients (n) } \\
\end{array}$ & $\begin{array}{l}\text { Raw Data } \\
\text { at the Last Available Follow-Up }\end{array}$ & $\begin{array}{c}\text { Extracted Data: } \\
\text { Functional Improvement } \\
\text { at the Last Available } \\
\text { Follow-Up (\%) }\end{array}$ \\
\hline Athanasakopoulos et al. ${ }^{17}$ & 2013 & ODI & 52 & Preop: $76.0 ; 12$ months: 30.0 & 60.5 \\
\hline Qi et al. ${ }^{18}$ & 2013 & JOA & 20 & Data were reported as percentage at 12 months & 76.9 \\
\hline \multirow{3}{*}{ Colangeli et al. ${ }^{19}$} & 2015 & ODI & 12 & Preop: $68.0 ; 12$ months: 24.0 & 64.7 \\
\hline & Total & & 84 & & Mean $=67.4 \pm 8.5$ \\
\hline & & & & & $\begin{array}{l}\text { Median }=64.7 \\
\text { Min }=60.5 ; \text { Max }=76.9\end{array}$ \\
\hline
\end{tabular}

Abbreviations: PEEK, polyetheretherketone; ODI, Oswestry Disability Index score; JOA, Japanese Orthopedic Association score.

Table 12. Functional improvement data in the controlled studies (PEEK versus titanium rods).

\begin{tabular}{llcccc}
\hline Author & Year & No. of Patients & $\begin{array}{c}\text { Average } \\
\text { Improvement }(\%)\end{array}$ & $\begin{array}{c}\text { Functional } \\
\text { Test }\end{array}$ \\
\hline Qi et al. ${ }^{18}$ & 2013 & 20 PEEK, 21 titanium & $\begin{array}{c}\text { At } 1 \text { year: } 76.9 \% \text { PEEK } \\
\text { versus } 77.6 \% \text { titanium }\end{array}$ & JOA & $\begin{array}{c}\text { At } 1 \text { year, no statistically significant } \\
\text { difference was observed }(P>.05)\end{array}$ \\
\hline
\end{tabular}

Abbreviation: PEEK, polyetheretherketone; JOA, Japanese Orthopedic Association.

Table 13. Summary of the pain improvement data in PEEK rod patients.

\begin{tabular}{|c|c|c|c|c|}
\hline Author & Year & $\begin{array}{l}\text { PEEK Rod } \\
\text { Patients (n) }\end{array}$ & Pain Improvement Raw Data & $\begin{array}{c}\text { Extracted Data: VAS Improvement } \\
\text { at the Last Follow-Up (\%) }\end{array}$ \\
\hline Athanasakopoulos et al. ${ }^{17}$ & 2013 & 52 & $\begin{array}{l}\text { VAS-BP: Preop }=8 ; \text { at } 36 \text { months }=2 \\
\text { VAS-LP: Preop }=9 ; \text { at } 36 \text { months }=2\end{array}$ & $\begin{array}{l}\text { VAS-BP: } 75.0 \% \\
\text { VAS-LP: } 77.7 \%\end{array}$ \\
\hline Qi et al. ${ }^{18}$ & 2013 & 20 & $\begin{array}{l}\text { VAS-BP: Preop }=7.0 \text {; at } 12 \text { months }=2.6 \\
\text { VAS-LP: Preop }=7.4 \text {; at } 12 \text { months }=1.8 \\
\text { The analysis of variance revealed that clinical } \\
\text { VAS-BP, and VAS-LP scores improved } \\
\text { significantly at } 3 \text { months, } 6 \text { months, and } 1 \text { year } \\
\text { postoperatively compared with the preoperative } \\
\text { scores }(P<.001) \\
\text { Note: Preoperative data were taken from Qi et al. }{ }^{18} \text {, } \\
\text { table } 1 \text { and postoperative data were deduced from } \\
\text { graphs in Qi et al. }{ }^{18} \text { figures } 1 \text { and } 2 \text {. }\end{array}$ & $\begin{array}{l}\text { VAS-BP: } 62.8 \% \\
\text { VAS-LP: } 75.6 \%\end{array}$ \\
\hline $\begin{array}{l}\text { Colangeli et al. }{ }^{19} \\
\text { Summary }\end{array}$ & 2015 & $\begin{array}{c}12 \\
\text { Total }=84\end{array}$ & VAS: Preop $=9.5 ;$ at 12 months $=4.0$ & $\begin{array}{l}57.9 \% \\
\text { VAS-BP: Mean }=68.9 \\
\quad \% \pm 8.6 \%, \text { Median }=68.9 \% \\
\text { Min }=62.8 \%, \text { Max }=75.0 \% \\
\text { VAS-LP: Mean }=76.6 \% \pm 1.5 \% \text {, } \\
\quad \text { Median }=76.6 \%, \text { Min } \\
\quad=75.6 \%, \text { Max }=77.7 \%\end{array}$ \\
\hline
\end{tabular}

Abbreviations: PEEK, polyetheretherketone; VAS-BP, visual analog scores-back pain; VAS-LP, visual analog scores-leg pain.

Table 14. VAS improvement data in the controlled studies (PEEK versus titanium rods).

\begin{tabular}{|c|c|c|c|c|}
\hline Author & Year & $\begin{array}{l}\text { Total No. } \\
\text { of Patients }\end{array}$ & VAS Improvement Mean (\%) & Notes \\
\hline Qi et al. ${ }^{18}$ & 2013 & $\begin{array}{l}20 \text { PEEK, } 21 \\
\text { titanium }\end{array}$ & $\begin{array}{l}\text { PEEK VAS-BP: Preop }=7.0 \text {; at } 12 \text { months }=2.6 \\
\text { Titanium VAS-BP: Preop }=6.5 \text {; at } 12 \text { months }=2.8 \\
\text { PEEK VAS-LP: Preop }=7.4 \text {; at } 12 \text { months }=1.8 \\
\text { Titanium VAS-LP: Preop }=7.2 \text {; at } 12 \text { months }=1.6^{\text {a }} \\
\text { VAS-BP improvement at } 12 \text { months: } \sim 63.4 \% \text { for the } \\
\text { titanium group and } \sim 66.2 \% \text { for the PEEK. } \\
\text { VAS-LP improvement: } \sim 72.0 \% \text { for the titanium group } \\
\text { and } 73.2 \% \text { for the PEEK. }\end{array}$ & $\begin{array}{l}\text { VAS-LP scores improved significantly at } \\
3 \text { months, } 6 \text { months, and } 1 \text { year } \\
\text { postoperatively compared with the } \\
\text { preoperative scores }(\mathrm{p}<0.001) \text { in } \\
\text { both groups. In the PEEK group, } \\
\text { patients showed a similar extent of } \\
\text { improvement respectively in VAS-BP } \\
\text { and VAS-LP scores at the same time } \\
\text { points postoperatively as compared to } \\
\text { patients in the TI group }(\mathrm{p}>0.05) \text {. }\end{array}$ \\
\hline
\end{tabular}

Abbreviations: PEEK, polyetheretherketone; VAS-BP, visual analog scores-back pain; VAS-LP, visual analog scores-leg pain.

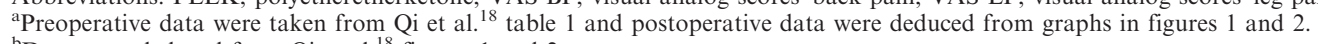

${ }^{\mathrm{b}}$ Data were deduced from Qi et al. ${ }^{18}$ figures 1 and 2. 
during the follow-up in PEEK group, but the extent of loss was similar to titanium group and therefore PEEK rods could meet the requirement in keeping lumbar lordosis and $\mathrm{DH}^{18}$

Quality of Life (QoL). Colangeli et al. ${ }^{19}$ reported a highly significant improvement in the life quality in PEEK rod-treated patients. In 12 cases treated by PEEK rods and IBF the average preoperative QoL value was 24 (range 0 to 60); the average postoperative QoL value was 74 (range 60 to 90, $P=.0002) .{ }^{19}$ These data are in alignment with the functional improvement outcomes.

Retrieval Analysis of PEEK Rods. As part of a prospective study organized to analyze explanted spinal devices and associated periprosthetic tissues collected at revision surgery, Kurtz and colleagues ${ }^{21}$ evaluated explanted PEEK rod spinal systems in the context of their clinical indications. Damage to the implant and histological changes in explanted periprosthetic tissues were evaluated. Retrieved components were assessed for surface damage mechanisms, including plastic deformation, scratching, burnishing, and fracture. Patient history and indications for PEEK rod implantation were obtained from analysis of the medical records. ${ }^{21}$

Twelve patients with PEEK rods underwent revision surgery, and their posterior instrumentation was retrieved. Patient age ranged from 35 to 64 years (mean $\pm \mathrm{SD}: 52 \pm 10$ years); 8 patients $(66.7 \%, 8 / 12)$ were female, and the implantation time of the PEEK rods ranged from 0.5 to 2.8 years $($ mean $\pm \mathrm{SD}: 1.7 \pm 0.8$ years $) .^{21}$

All the patients in this study were revised for intractable pain, although the mechanism varied and was confirmed by intraoperative findings. The most frequently reported reasons $(58.0 \%, 7 / 12)$ for revision among the PEEK rod patients who underwent spinal fusion included adjacent segment disease in 3 patients, device-related muscular paravertebral pain in 2 patients, and pseudoarthrosis in 2 patients. The revision procedures were performed via a posterior approach. ${ }^{21}$

Eleven of the 12 PEEK rod systems were employed for fusion at one level and motion preservation at the adjacent level. There were no cases of PEEK rod fracture or pedicle screw fracture. Retrieved PEEK rods exhibited scratching, as well as impressions from the set screws and pedicle screw saddles. PEEK debris was observed in
2 patient tissues, which were located adjacent to PEEK rods with evidence of scratching and burnishing. Kurtz and colleagues ${ }^{21}$ did not attribute any complications to this PEEK debris.

Kurtz and colleagues ${ }^{21}$ concluded that PEEK rods were associated with similar clinical risks to those posed by traditional metal rod systems used for posterior lumbar fusion, and that the reasons for PEEK rod system revisions, including pseudoarthrosis, device-related pain, disease progression, and unrecognized adjacent-level disease, were well documented in the literature for metallic posterior fusion systems. Because their study was limited to a relatively small number of cases requiring surgical intervention and instrumentation removal, Kurtz and colleagues ${ }^{21}$ also concluded that their study could not be used to establish the overall revision or complication risk for the clinical use of PEEK rods. Moreover, many of their cases were salvage procedures with a history of previous spinal surgeries, which were more difficult than primary fusions. Kurtz and colleagues ${ }^{21}$ stated, nevertheless, that the findings from this relatively small series of revision cases were a positive complement to the data obtained in prospective clinical studies. ${ }^{21}$

\section{DISCUSSION AND CONCLUSIONS}

The purpose of this study was to evaluate the safety and effectiveness of the use of PEEK rods in the IBF procedures. The systematic review included 5 studies and analyzed the following data: the rates of rod fracture, screw fracture, and screw loosening; fusion success rates; and the percentages of pain and function improvement (Tables 2 to 4 ).

No rod fractures were reported in any study, and the average rates of screw fractures and screw loosening were $2.6 \%$ and $2.0 \%$, respectively (Table $8)$. In the controlled study, no significant difference between these rates was reported (Table 9).

The estimate of IBF success rate was $95.6 \%$ (Table 6 ; Figure 2). In the controlled study, ${ }^{18}$ the fusion success rate was $100.0 \%$ in both treatment groups (Table 10). The possible confounding effect of the graft type and the number of the treated levels on the fusion success rates was examined, and no significant difference was observed (Table 7, Figures 3 and 4).

When comparing preoperative to postoperative function scores, PEEK rod patients demonstrated clinically meaningful improvement with an average improvement of $67.4 \%$ (Table 11). Additionally, the functional improvement magnitudes in the con- 
trolled study ${ }^{18}$ were similar in the PEEK and titanium groups (Table 12).

PEEK rod patients had significant VAS improvements when comparing pre- to postoperative scores at an average change of $68.9 \%$ and $76.6 \%$ for VASBP and VAS-LP, respectively (Table 13). Moreover, the controlled study VAS data showed no significant difference between titanium and PEEK rodtreated patients (Table 14).

Our inferences are in agreement with the findings of other individual studies and reviews. ${ }^{7,8}$ Mavrogenis et al. ${ }^{7}$ evaluated the use of PEEK rod systems for spine stabilization. Their review discussed the effect of this device in fusion and nonfusion spine stabilization procedures. The authors concluded that early practice with PEEK rod systems has shown biomechanical compliance with physiological spinal movement, increased fusion success rates, minimum complications, and reduced adjacent segment degeneration. The authors noted that these results reserve a significant place for the use of PEEK in spinal surgery. ${ }^{7}$

Li et al. $^{8}$ conducted a systematic review to evaluate the use of PEEK rod systems in fusion and nonfusion spine stabilization procedures. No single PEEK rod break was reported and the IBF rate varied from $89.3 \%$ to $100 \%$. Li concluded that PEEK rod systems can be used for semirigid fusion for the treatment of degenerative disc disease and mild lumbar spondylolisthesis. ${ }^{8}$

It is important to note that this study has some shortcomings, including the small number of studies (5), and their low evidence levels (III and IV). However, this report may lay the foundation for higher-level studies in the future.

In summary, the data demonstrated satisfactory fusion success rates and clinically meaningful percentages of functional and pain improvements as well as low rates of device-related events. These outcomes suggest that there are sufficient foundations to support the use of PEEK rods as an adjunct to IBF.

\section{REFERENCES}

1. Kurtz SM, Devine JN. PEEK biomaterials in trauma, orthopedic, and spinal implants. Biomaterials. 2007;28(32):48454869.

2. Narayan P, Haid RW, Subach BR, Comey CH, Rodts GE. Effect of spinal disease on successful arthrodesis in lumbar pedicle screw fixation. J. Neurosurg. 2002;97(3 Suppl):277-280.

3. Ponnappan RK, Serhan H, Zarda B, Patel R, Albert T, Vaccaro AR. Biomechanical evaluation and comparison of polyetheretherketone rod system to traditional titanium rod fixation. Spine J. 2009;9(3):263-267.

4. Highsmith JM, Tumialan LM, Rodts GE Jr. Flexible rods and the case for dynamic stabilization. Neurosurg Focus. 2007;22(1):E11.

5. Cavagna R, Tournier C, Aunoble S, Bouler JM, Antonietti $\mathrm{P}$, Ronai $\mathrm{M}$, et al. Lumbar decompression and fusion in elderly osteoporotic patients: a prospective study using less rigid titanium rod fixation. J. Spinal Disord Tech. 2008;21(2):86-91.

6. Sarbello JF, Lipman AJ, Hong J, et al. Patient perception of outcomes following failed spinal instrumentation with polyetheretherketone rods and titanium rods. Spine. 2010 Aug 1;35(17):E843-E848.

7. Mavrogenis AF, Vottis C, Triantafyllopoulos G, Papagelopoulos PJ, Pneumaticos SG. PEEK rod systems for the spine. Eur J Orthop Surg Traumatol: Orthopedie Traumatologie. 2014;24(Suppl 1):S111-S116.

8. Li C, Liu L, Shi JY, Yan KZ, Shen WZ, Yang ZR. Clinical and biomechanical researches of polyetheretherketone (PEEK) rods for semi-rigid lumbar fusion: a systematic review. Neurosurg Rev. 2018;41(2):375-389.

9. Wallace BC, Dahabreh IJ, Trikalinos TA, Lau J, Trow $\mathrm{P}$, Schmid $\mathrm{CH}$. Closing the gap between methodologists and end-users: R as a computational back-end. J Stat Software. 2012;49(5):1-5.

10. Huang W, Chang Z, Song R, Zhou K, Yu X. Nonfusion procedure using PEEK rod systems for lumbar degenerative diseases: clinical experience with a 2-year followup. BMC Musculoskeletal Disord. 2016;17(1):53.

11. Enercan MGB, Kahraman S, Cobanoglu M, et al. Clinical results of dynamic stabilization adjacent to fusion level: a new lumbar hybrid instrumentation. Eur Spine J. 2015;24(6, Suppl. 1):S764.

12. Bono CM, Kadaba M, Vaccaro AR. Posterior pedicle fixation-based dynamic stabilization devices for the treatment of degenerative diseases of the lumbar spine. J. Spinal Disord Tech. 2009;22(5):376-383.

13. Pape H, Ringel F, Behr M, Meyer B, Stoffel M. Feasibility, safety and efficacy using peek rods with interbody graft support for a topping-off technique in a hybrid-system for dorsal stabilization of lumbar instabilities - preliminary results of a prospective single-center observation. Eur Spine J. 2010;19(11):P159.

14. Pape HRF, Obermüller T, Wostrack M, Kuhlen D, Meyer B. Hybrid stabilization with rigid levels and 'topping-off' for multi-level degenerative lumbar instabilities-preliminary results of a series of 173 consecutive patients. 64th Annual Meeting of the German Society of Neurosurgery (DGNC). 2013.

15. North American Spine Society. Levels of Evidence For Primary Research Question as Adopted by the North American Spine Society. 2005. https://www.spine.org/Documents/ ResearchClinicalCare/LevelsOfEvidence.pdf.

16. De Iure F, Bosco G, Cappuccio M, Paderni S, Amendola L. Posterior lumbar fusion by peek rods in degenerative spine: preliminary report on 30 cases. Eur Spine J. 2012;21(Suppl):S50-S54.

17. Athanasakopoulos M, Mavrogenis AF, Triantafyllopoulos G, Koufos S, Pneumaticos SG. Posterior spinal fusion using pedicle screws. Orthopedics. 2013;36(7):e951-e957.

18. Qi L, Li M, Zhang S, Xue J, Si H. Comparative 
effectiveness of PEEK rods versus titanium alloy rods in lumbar fusion: a preliminary report. Acta Neurochirurgica. 2013;155(7):1187-1193.

19. Colangeli S, Barbanti Brodano G, et al. Polyetheretherketone (PEEK) rods: short-term results in lumbar spine degenerative disease. J Neurosurg Sci. 2015;59(2):91-96.

20. Ormond DR, Albert L Jr, Das K. Polyetheretherketone (PEEK) rods in lumbar spine degenerative disease: a case series. Clin Spine Surg. 2016;29(7):E371-E375.

21. Kurtz SM, Lanman TH, Higgs G, et al. Retrieval analysis of PEEK rods for posterior fusion and motion preservation. Eur Spine J. 2013;22(12):2752-2759.

Corresponding Author: Abdulhafez Selim,
MD, PhD, Medtronic Spinal, Clinical Research, 1800 Pyramid Place, Memphis, TN 38132. Phone: (908) 415-2593; Email: abdulhafez.selim@ medtronic.com.

Published 3 August 2018

This manuscript is generously published free of charge by ISASS, the International Society for the Advancement of Spine Surgery. Copyright (C) 2018 ISASS. To see more or order reprints or permissions, see http://ijssurgery.com. 